\title{
Comment: update on the management of constipation in the elderly: new treatment options
}

\section{Lee Techner}

Adolor Corporation, Exton, PA, USA
Correspondence: Lee Techner DPM Adolor Corporation, 700 Pennsylvania Drive, Exton, PA 1934I, USA Fax + I 484595 I5 I3

Email itechner@adolor.com
This article was published in the following Dove Press journal:

Clinical Interventions in Aging

10 December 2010

Number of times this article has been viewed

To the editor,

I read with great interest the recent article by Rao and Go regarding new treatment options for the management of constipation in the elderly. ${ }^{1}$ In this article, alvimopan was described as having been "recently...introduced for the treatment of opioid-induced constipation". Furthermore, alvimopan was included in a treatment algorithm for management of opioid-induced chronic constipation in the elderly (see Figure 1 in Rao and Go). ${ }^{1}$ Additionally, other "potential uses" for peripherally acting mu-opioid receptor antagonists (including alvimopan) were identified by the authors and included treatment of "opioid-related nausea and vomiting, urinary retention, pruritus or post-operative ileus". This characterization of alvimopan requires further clarification.

Alvimopan was approved by the US Food and Drug Administration (FDA) in 2008 for the acceleration of gastrointestinal recovery following partial small or large bowel resection with primary anastomosis. ${ }^{2}$ Alvimopan has not been approved for any other indication, such as treatment of opioid-induced constipation. Importantly, the Warnings and Precautions section of the label describes the potential adverse effects that may be associated with administration of alvimopan $12 \mathrm{mg}$ to patients recently exposed to opioids. Furthermore, alvimopan is approved only for short-term, in-hospital use, and hospitals dispensing alvimopan must register in and meet all of the requirements of the Entereg ${ }^{\circledR}$ Access Support and Education (E.A.S.E.TM) Program. ${ }^{3}$

It is important that your readers understand these facts about alvimopan use in light of the information provided by Rao and Go.

\section{Disclosure}

Lee Techner, DPM, is the Vice President of Medical Affairs and Pharmacovigilance/ Drug Safety at Adolor Corporation, the company that developed and is comarketing Entereg ${ }^{\circledR}$ (alvimopan).

\section{References}

1. Rao SSC, Go JT. Update on the management of constipation in the elderly: new treatment options. Clin Interv Aging. 2010;5:163-171. 
2. Adolor Corporation. Entereg ${ }^{\circledR}$ (alvimopan) Capsules. Prescribing Information. Available at: http://www.entereg.com/images/documents/ prescribing-information.pdf. Accessed 2010 Aug 30.
3. Adolor Corporation. Entereg (alvimopan) Capsules. Entereg ${ }^{\mathbb{}}$ E.A.S.E. ${ }^{\text {TM }}$ Program. Available at: http://www.entereg.com/content/e_a_s_e_program/. Accessed 2010 Aug 30 .

\section{Publish your work in this journal}

Clinical Interventions in Aging is an international, peer-reviewed journal focusing on evidence-based reports on the value or lack thereof of treatments intended to prevent or delay the onset of maladaptive correlates of aging in human beings. This journal is indexed on PubMed Central, MedLine, the American Chemical Society's 'Chemical Abstracts
Service' (CAS), Scopus and the Elsevier Bibliographic databases. The manuscript management system is completely online and includes a very quick and fair peer-review system, which is all easy to use. Visit http://www.dovepress.com/testimonials.php to read real quotes from published authors.

Submit your manuscript here: http://www.dovepress.com/clinical-interventions-in-aging-journal 